\title{
Socioeconomic Conflict between Host Community and Syrian Refugees in Urban Turkey: The Mediating Role of Political Trust
}

\section{Türkiye'de Kentsel Alanda Ev Sahibi Topluluklar ve Suriyeli Mülteciler Arasında Yaşanan Sosyoekonomik Uyuşmazlıkta Siyasal Güvenin Rolü}

\author{
Halil Pak ${ }^{1}\left(\mathbb{0}\right.$, Zeliha Aslı Elitsoy² $^{2}$
}

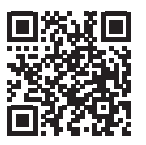

Author Note: The initial part of this study was presented at the $2^{\text {nd }}$ Witten Conference on Institutional Change: Migration, Institutions, and Institutional Change, Herdecke University in Witten, Germany.

'Lecturer, Izmir University of Economics, Vocational School, Izmir, Turkey ${ }^{2}$ PhD Candidate, Bilkent University, Department of Political Science and Public Administration, Ankara, Turkey

ORCID: H.P. 0000-0002-8248-9158; Z.A.E. 0000-0003-0786-0460

Corresponding author/Sorumlu yazar: Halil Pak,

Izmir University of Economics, Vocational School, Izmir, Turkey

E-mail/E-posta: halilpak88@gmail.com

Submitted/Başvuru: 25.12.2019

Revision Requested/Revizyon Talebi: 19.05.2020

Last Revision Received/Son Revizyon: 08.06.2020

Accepted/Kabul: 25.06.2020

Published Online/Online Yayın: 16.11.2020

Citation/Atıf: Pak, H., \& Elitsoy, Z. A. (2020). Socioeconomic conflict between host community and Syrian refugees in urban Turkey: The mediating role of political trust Psikoloji Çalışmaları - Studies in Psychology, 40(2): 579-597.

https://doi.org/10.26650/SP2019-0094

\section{ABSTRACT}

This study investigated socioeconomic conflict between the host community and Syrian refugees in urban Turkey. It was aimed to explore the mediating role of political trust in the relationship between personal economic satisfaction and socioeconomic threat perception toward refugees among the host community. Accordingly, 243 local urban residents from different cities of Turkey including Istanbul, Ankara, and Izmir were reached using a cross-sectional survey approach and convenience sample method. Regarding the Turkish political, social and economic culture and previous studies, assessment tools were generated for the purpose of this study to measure socioeconomic threat perception, personal economic satisfaction, political trust, and satisfaction with public policies. The participants' age, city, education, gender and income information were obtained using a demographic form. Data was collected via an online survey program. Controlling for demographic variables (age, city, education, gender, and income) and satisfaction with public services, the indirect effect of political trust was analyzed using a bootstrapping method via PROCESS Macro plug-in for SPSS. The research findings showed that personal economic satisfaction was significantly associated with political trust and socioeconomic threat perception. Moreover, political trust was also significantly related to socioeconomic threat perception. More importantly, in accordance with the main hypothesis of the study, it was found that political trust mediated the relationship between personal economic satisfaction and socioeconomic threat perception. According to this result, it can be said that less satisfaction with personal economic conditions led to less political trust, which then resulted in greater socioeconomic threat perception toward refugees. The results were discussed in the light of previous findings, Integrated Threat Theory, Realistic Group Threat Theory, and System Justification Theory. Lastly, limitations and suggestions for future research were evaluated in the discussion part of the study.

Keywords: Integrated Threat Theory, socioeconomic threat, personal economic satisfaction, political trust, host community, refugees 


\section{ÖZ}

Bu çalışmada, Türkiye'nin kentsel alanlarında yaşayan ev sahibi topluluklar ile Suriyeli mülteciler arasında yaşanan sosyoekonomik uyuşmazlık araştırılmıştır. Çalışmanın amacı ev sahibi topluluk üyelerinin kişisel ekonomik tatmin düzeyleri ve mültecilere yönelik sosyoekonomik tehdit algıları arasındaki ilişkide siyasal güvenin aracı rolünü keşfetmektir. Kesitsel anket çalışması yaklaşımıyla ve kolayda örnekleme yöntemiyle başta İstanbul, Ankara ve İzmir olmak üzere Türkiye'nin farklı kentsel bölgelerinde yaşayan 243 yerel sakinden çevrimiçi anket programı yoluyla veri toplanmıştır. Türkiye'nin siyasal, sosyal ve ekonomik kültürü ve geçmiş çalışmalar göz önünde bulundurularak, bu araştırmanın amaçları doğrultusunda algılanan sosyoekonomik tehdit algısı, kişisel ekonomik tatmin düzeyi, siyasal güven ve kamusal hizmetlerden memnuniyet değişkenleri için ölçüm araçları tasarlanmıştır. Demografik form aracılığıyla da katılımcıların yaş, şehir, eğitim, cinsiyet ve gelir bilgilerine ulaşılmıştır. SPSS programında PROCESS Macro eklentisi üzerinden yeniden örnekleme metodu kullanılarak ve demografik değişkenler (yaş, şehir, eğitim, cinsiyet, gelir) ve kamusal hizmetlerden memnuniyet değişkenleri kontrol edilerek siyasal güvenin dolaylı etkisi analiz edilmiştir. Araştırmanın bulgularına göre, kişisel ekonomik tatminin siyasal güvenle ve algılanan sosyoekonomik tehditle anlamlı bir ilişkiye sahip olduğu görülmüştür. Ayrıca, siyasal güvenin sosyoekonomik tehdit algısıyla da anlamlı bir ilişkiye sahip olduğu görülmüştür. Asıl önemlisi, çalışmanın ana hipotezi olan siyasal güvenin, kişisel ekonomik tatmin ve algılanan sosyoekonomik tehdit ilişkisinde anlamlı bir aracı rolü olduğu sonucuna ulaşılmıştır. Bu sonuca göre, düşük kişisel ekonomik tatmin düzeyinin düşük siyasal güvene yol açtığı ve bu durumun da mültecilere yönelik yüksek sosyoekonomik tehdit algısına neden olduğu söylenebilir. Çalışmanın sonuçları, literatürdeki geçmiş çalışmalar, Bütünleşik Tehdit, Gerçekçi Grup Tehdit ve Sistemi Meşrulaştırma Kuramları üzerinden tartışılmıştır. Araştırmanın kısıtları ve gelecek çalışmalar için öneriler çalışmanın tartışma kısmında değerlendirilmiştir.

Anahtar Kelimeler: Bütünleşik Tehdit Kuramı, sosyoekonomik tehdit, kişisel ekonomik tatmin, siyasal güven, ev sahibi topluluk, mülteciler 
One of the most devastating outcomes of the Arab uprisings is the Syrian War started in March 2011. For almost one decade, the Syrian War has caused a serious humanitarian crisis and forced about six million refugees to flee to neighboring countries, including Turkey, Lebanon, Jordan, Iraq and Egypt. According to the United Nations High Commissioner for Refugees (2019), the number of registered Syrian refugees is about 3.7 million in Turkey, which makes it the country with the world's largest refugee population. Indeed, the increase in the Syrian refugee population has led to some economic consequences at a national level. To illustrate, President Recep Tayyip Erdoğan issued a press statement that \$33 billion has been spent up to date for Syrian refugees (Hacaoğlu, 2018).

A public opinion survey on social acceptance and integration of Syrian refugees in Turkey conducted by Hacettepe University, Migration and Politics Research Center (Erdoğan, 2014) showed that host citizens perceived Syrian refugees as an economic burden and threat, and of the respondents, $71 \%$ thought that the Turkish economy has suffered because of Syrian refugees. In addition, $61 \%$ reported that the government revenue from taxes should be used for the citizens who are in need of help rather than for the Syrian refugees. Moreover, $56 \%$ of participants further believed that Syrian refugees have taken their jobs, and so, about 50\% did not agree with granting work permits to Syrians. This study also compared those who live in "the region" (Adana, Gaziantep, Hatay, Mardin and Sanliurfa) to those who live "outside of the region" (Ankara, Antalya, Balikesir, Bursa, Erzurum, Istanbul, Izmir, Kayseri, Konya, Malatya, Samsun, Trabzon and Van), where the region refers to the Turkey's neighboring provinces to Syria. The comparison results showed that, of the participants, $44 \%$ from the region and $48 \%$ outside of the region agreed with that Syrian refugees should not be granted work permits. This result is interesting because those who did not support work permits for Syrian refugees were higher among individuals outside of the region. On the other hand, according to the International Crisis Group's European Report (2018) entitled “Turkey's Syrian Refugees: Defusing Metropolitan Tensions", hostility toward Syrian refugees among host residents was also on the rise in urban settings. These two public opinion survey reports provide evidence that there has been a rising socioeconomic tension between urban local residents and Syrian refugees in Turkey. Nonetheless, there have been limited studies (e.g., Erçetin, 2016; Navruz \& Çukurçayır, 2015 ) figuring out the underlying mechanisms of this tension in urban Turkey.

Regarding these two public opinion surveys and current discussions in the literature, the present study was designed to explore the factors associated with socioeconomic 
threat perception toward Syrian refugees with a particular focus on host community residents in urban Turkey. Particularly, the purpose of the study was to address the following questions: Do host community residents in urban Turkey perceive Syrian refugees as a socioeconomic threat? Is there an association between local residents' personal economic well-being and their trust in political institutions? Is political trust related to socioeconomic threat perception? Finally, does political trust have a mediating role in the relationship between personal economic satisfaction and socioeconomic threat perception? Although there are some answers to the study's research questions in social psychological theories of prejudice and discrimination, a possible answer for the last question is still unclear.

\section{Socioeconomic Threat, Personal Economic Satisfaction and Political Trust}

There are two main types of perceived threats toward foreigners in the literature (Hochman, 2015). The first is socioeconomic threat that perceives competition for scarce resources with a respective outgroup that leads to an intrinsic conflict of interest in a given ingroup. The second is symbolic or namely ethnonational threat which is associated with the Social Identity Theory (Tajfel, 1981; Tajfel \& Turner, 1979). This theory argues that individuals endeavoring for a positive self-concept among others tend to depict the ingroup as superior and discrete from outgroups in order to secure positive group identification (Hochman, 2015). On the other hand, according to the Integrated Threat Theory developed by Stephan and Stephan (2000), outgroup members as "others" represent a threat in intercultural relations based on inter-ethnic prejudices. This theory also presents a clarification for economic conflict between ingroup and outgroup members through the concept of realistic threat. Precisely, realistic threat, one of the components of this theory, is defined as a driver of prejudice associated with certain threats perceived by ingroup members to their existence, physical well-being, and political and economic power.

The existing literature on socioeconomic threat mainly focuses on the relationship between ingroup and outgroup behaviors regulated by political, social and economic environments (Blalock, 1967; Fritsche et al., 2017; Hochman, 2015; LeVine \& Campbell, 1972). Socioeconomic threat can be explained by the Realistic Group Threat Theory (Blalock, 1967); "perceived competition over scarce resources such as jobs or social benefits between a given ingroup and a respective outgroup leads to an inherent conflict of interest between two groups" (Hochman, 2015, p. 363). Furthermore, 
Kamiejski, de Oliveira and Guimond (2012) posit a relationship between the theories of realistic threat and realistic group conflict, that is, the intergroup competition for scarce resources such as land, power and jobs as the main sources of hostile inter-group relations generate a threat perception toward outgroup members. Thus, regarding the empirical evidences from previous studies, they argue that there can be an association between realistic threat feelings and prejudice toward immigrants in various settings.

There have been a few studies on threat perceptions toward Syrian refugees in Turkey. For instance, Yitmen and Verkuyten (2018) revealed that national identification had an indirect effect on behavioral intentions toward Syrian refugees through threat perception in Turkey. In other words, higher national identification among host community members led to greater threat perception of Syrian refugees toward national security and identity, and then resulted in greater negative intentions. On the other hand, Köse, Sunata and Deniz (2018) investigated perceived socioeconomic and political threat toward Syrian refugees and its relation to social dominance orientation, social egalitarianism and empathy levels of local urban residents. They explored these relations through the Intergroup Contract Theory (Allport, 1954) and the Integrated Threat Theory (Stephan \& Stephan, 2000) by comparing threat perceptions of heavily and nondensely populated areas in Ankara, Turkey. They concluded that Syrian refugees were perceived as a socioeconomic threat in both areas among the local residents who considered themselves superior to the refugees. Further, the residents of heavily populated areas reported higher levels of social egalitarianism compared to the residents of non-densely populated areas who reported lower levels of perceived socioeconomic and political threat toward Syrian refugees. However, they did not find a significant relationship between empathy and threat perception in both areas.

Furthermore, Topal, Özer and Dokuzlu (2017) conducted a study about how the host community perceived Syrian refugees in Turkey. They developed and tested a proposed model called the Extended Integrative Threat Theory model that proposes host citizens perceive refugees not only as a threat but also as a benefit. In accordance with this model, they showed that although refugees were perceived as a threat to the Turkish economy, host community members tended to welcome Syrian refugees because they believed that it was a human duty. Girgin and Cebeci (2017) further demonstrated that high-skilled native laborers did not see refugees as an economic threat since they believed that they could not obtain work permits in a short time. However, they also added that Syrian 
refugees in Turkey created an advantage for employers by supplying cheap labor possibly causing an increase in economic threat perception of refugees among the unqualified native laborers, which is indicative of a socioeconomic conflict based on personal economic wellbeing between host community and refugees. Personal economic satisfaction is a category of personal employment satisfaction, of which job, job security, and job opportunities, current income level, and future financial security are indicators (Filkins, Allen, \& Cordes, 2000). Lawrence (2011) describes personal economic satisfaction as perceived personal and familial economic situation. On the strength of his research on immigration attitudes in Latin America, a perceived disadvantage for personal economic satisfaction resulted in less tolerance toward immigrants. Unqualified laborers tended to become less receptive to immigrants because of their self-economic interests in the labor market. Therefore, the first hypothesis of this study follows as:

H1. Personal economic satisfaction is negatively associated with the perception of refugees as a socioeconomic threat.

According to Wang (2005), political trust is a complex concept. Regarding the Norris' (1999) analysis, he defines political trust as attitude toward national government, parliament, and political parties. Wong, Wan and Hsiao (2011) also identify political trust as confidence in government and evaluative orientations toward the political system based on the public's normative expectations. Similarly, Grönlund and Setälä (2007) argue that political trust refers to normative expectations toward political institutions and actors (p. 400). On the other hand, for some other scholars, political trust is related to satisfaction with political institutions and actors (Jeannet, 2013; Miller, 1974; Saad \& Salman, 2013). For instance, Miller (1974) describes political trust as a simple barometer of satisfaction with the political system (p. 971). Moreover, Saad and Salman (2013) define political trust as a belief toward the community leaders with an emphasis on satisfaction with government and perception of politicians having the knowledge of societal needs and changes. In the light of this evidence, it can be concluded that political trust is an attitude or belief based on normative evaluations toward political systems, institutions and actors such as government, political parties, and parliaments. In other words, it refers to satisfaction with the political system, institutions and actors.

There has been a rising sociopolitical young class among the conservatives in Turkey, which is called the M generation (Janmohamed, 2018). In 2017, Wizsight 
Research conducted a survey of 700 participants to figure out the attributes and behaviors of the M generation in Turkey. Specifically, the M generation are those who are under 35 and identify themselves as Muslim and modern with their authentic consumption patterns hybridizing Islamic and modern symbols and meanings in a material sense. Namely, the M generation represents the modern urban conservatives in contemporary Turkey. They are fashionista and consumerist compared to traditional and religious conservatives. The research findings showed that there was a positive relationship between level of income and voting for the Justice and Development Party (JDP). Indeed, the present study did not focus on the $M$ generation, but this public opinion research illustrated that personal economic wellbeing and political trust are associated as previous studies also confirmed (Mason, Kluegel, \& Khakhulina, 2000; Wang, 2005). Furthermore, political trust and political support are also associated constructs (Easton, 1957; Jeannet, 2013). Therefore, it can be assumed that such progovernment individuals who are satisfied with personal economic conditions tend to support governmental policies and decisions. The second hypothesis is:

H2. Personal economic satisfaction is positively correlated with political trust.

Moreover, it can be disputed that political trust is related to socioeconomic threat perception toward refugees. However, considering the pro-government attitudes of the M generation (Janmohamed, 2018; Wizsight Research, 2017) and previous studies (Easton, 1957; Jeannet, 2013), a negative direction is expected in this relationship. Accordingly, the following hypothesis is formulated:

H3. Political trust is negatively related to perceived socioeconomic threat toward refugees among host community.

Lastly, the primary objective of this study is to address the gap in the literature mentioned above. Therefore, it is mainly hypothesized that personal economic satisfaction has an indirect effect on socioeconomic threat perception of refugees through political trust. However, satisfaction with public services is related to political trust (Ariely, 2013). For Kampen, Van De Walle and Bouckaert (2006), there are adequate empirical evidences for correlational association between satisfaction with public services and political trust (See also Kampen, Maddens, \& Vermunt, 2003; Van Ryzin, Muzzio, \& Immerwahr, 2004). In addition to satisfaction with public services, Muñoz, Torcal and Bonet (2011) also showed that age, gender and education were the 
predictors of political trust. On the other hand, age, gender and income of host citizens have no significant effect on threat or benefit perceptions of refugees except for education (Topal et al., 2017). According to a study conducted by Yitmen and Verykuyten (2018), gender and city were significant predictors of the moderated mediation relationship among national identification, perception of threat and behavioral intentions toward refugees. Nonetheless, their additional analysis without control variables (gender and city) did not change the findings. To conclude, the literature showed strong evidence for the correlational relationship between satisfaction with public services and political trust, but few studies indicated limited evidence for demographics as predictors of political trust and socioeconomic threat. However, the current study is observational; therefore, demographic variables were also regarded as covariates. As a result, age, city, education, gender, income and satisfaction with public policies were included as control variables in the hypothesized model. Hence, the last hypothesis is generated as:

H4. Personal economic satisfaction has an indirect effect on socioeconomic threat perception toward refugees through political trust when controlling for age, city, education, gender, income, and satisfaction with public policies.

As discussed earlier, socioeconomic threat is the perception of refugees as a threat to the national economy and employment opportunities by the host community (Girgin \& Cebeci, 2017; Hochman, 2015; Kamiejski et al., 2012; Topal et al., 2017; Yitmen \& Verkuyten, 2018). However, scales assessing the host citizens' perceptions of foreigner workers as a socioeconomic threat are very limited. For example, Gorodzeisky (2013) used a six-item scale to measure the Israelis' perception of foreign workers as such a threat. The scale items were "Foreign workers are strain on the welfare services system", "Foreign workers can hurt welfare services that you are entitled to", "Foreign workers take jobs from Israelis", "Foreign workers can hurt employment opportunities", "The presences of foreign workers lowers the Israelis' wage level", and "Foreign workers can hurt your wage level". Although this scale measured socioeconomic threat focusing on social services and employment opportunities, the national economy was not taken into consideration. Also, Schnrider (2016) argues that some scholars measuring political trust do not have theoretical justifications. In other respects, Zhong (2014), considering Li's (2011) addressing validity issues in global and generic measures of political trust, assessed political trust over the efforts undertaken by central and municipal governments to the right things for the people in China. In connection with previous works and suggestions, 
measures regarding Turkish political, social and economic culture were generated to assess the perception of refugees as socioeconomic threat, personal economic satisfaction, political trust, and satisfaction with public policies for the purpose of this study.

\section{METHOD}

\section{Participants}

Respondents were 243 urban local residents. Of the sample, 145 (60\%) were female. Age ranged from 19 to $64(M=32.02, S D=8.63)$. Two hundred and twelve $(87 \%)$ had a university degree, and $31(13 \%)$ had a high school degree. All of the participants were adult Turkish citizens, with a mean income of $£ 3,754$ per month (TRY £1 equals approximately USD \$0.13). Of the respondents, 131 (55\%) were from Istanbul, 46 (19\%) from Ankara, 17 (7\%) from Izmir, and 49 (19\%) from other cities.

\section{Measures}

Demographic Information Form. A brief questionnaire was used to obtain demographic information including age, city, education, gender and income.

Socioeconomic Threat. A four-item questionnaire considering the study of Erdoğan (2014) was designed to measure socioeconomic threat based on the questionnaires of economic burden and right to labor. Items used in this study were "Turkish economy suffers because of Syrian refugees", "I oppose my taxes spent on Syrian refugees while there are many other citizens in need of help in Turkey", "Syrians take our jobs", "Syrians should not be granted work permission" Items were rated on a 5-point Likert-type scale (from 1 = Strongly disagree to $5=$ Strongly agree). An average score of these items was computed. A higher mean suggests greater perceived socioeconomic threat $(\alpha=.87)$.

Political Trust. Depending upon the most significant studies in the field (Miller, 1974; Jeannet, 2013; Norris, 1999), a three-item measure was designed for the assessment of political trust: "I am satisfied with the current government", "I am satisfied with being politically represented in the Turkish Grand National Assembly", "I am satisfied with the Turkish political system" ${ }^{\text {"1 }}$ Items were rated on a 5-point Likerttype scale (from $1=$ Strongly disagree to $5=$ Strongly agree). An average score of these items was computed. A higher mean reflects greater political trust $(\alpha=.72)$.

1 Turkey was a parliamentary regime when this study was conducted. Later in 2018, Turkey adopted a regime change, transforming Turkey from a parliamentary regime into a presidential one. 
Personal Economic Satisfaction. A three-item scale was designed to measure personal economic satisfaction in consideration of the Life Satisfaction Survey annually conducted by the Turkish Statistical Institute: "I am satisfied with my monthly income", "In addition to my basic needs (e.g., housing, food, transportation), I can also spend on other things (e.g., holiday, entertainment)", "There is a satisfactory balance between my income and expenses" Items were rated on a 5-point Likert-type scale (from $1=$ Strongly disagree to $5=$ Strongly agree). An average score of these items was computed. A higher mean indicates greater personal economic satisfaction $(\alpha=.84)$.

Satisfaction with Public Services. A six-item questionnaire was used to assess satisfaction with public services based on the Turkish Statistical Institute's annual research of Life Satisfaction Survey: "Services of social security institution", "Health services", "Educational services", "Judicial services", "Public security services", "Transportation services". Responses were rated on a 5-point Likert-type scale (from 1= Very dissatisfied to $5=$ Very satisfied). An average score of these items was computed. A higher mean demonstrates greater satisfaction with public services $(\alpha=.89)$.

Put in a nutshell, for each measure, coefficient alphas ranged from .72 to .89, and according to Nunnally and Bernstein (1994), all assessment tools designed for the purpose of this study are acceptable.

\section{Procedure and Data Analysis}

Following informed consent, data were collected from the convenience sample living in different urban cities of Turkey between June and August 2015 using an online survey program. The statistical package, SPSS, was used for data analysis. Further, a bootstrapped mediation analysis was conducted via the PROCESS Macro plug-in for SPSS (Hayes, 2013) to examine the indirect effect of personal economic satisfaction and socioeconomic threat through political trust, controlling for age, city, education, gender, income, and satisfaction with public services. Before performing mediation analysis, multivariate outliers were eliminated using indices from Mahalanobis distance, Cook's values and leverage (Schulenberg, Schnetzer, \& Buchanan, 2011). Consequently, 10 outliers as large multivariate outlier indicators were removed. The prediction was tested with 10,000 bootstrapping resamples and bias-corrected 95\% Confidence Intervals (CIs) for the indirect effect. 


\section{RESULTS}

The means, standard deviations, internal consistency reliability coefficients, and correlations of and among the measurements are given in Table 1. Bivariate correlations among outcome and predictor variables were in the expected directions.

Table 1. Means, Standard Deviations, Internal Consistency Reliability Coefficients, and Correlations of and among the Measures

\begin{tabular}{lcccccc}
\hline Measure & $\boldsymbol{M}$ & $\boldsymbol{S D}$ & $\mathbf{1}$ & $\mathbf{2}$ & $\mathbf{3}$ & $\mathbf{4}$ \\
\hline 1. Socioeconomic threat & 3.16 & 1.21 & $(.87)$ & $-.14^{*}$ & $-.13^{*}$ & .04 \\
2. Personal economic satisfaction & 2.49 & 1.10 & & $(.84)$ & $.41^{* *}$ & $.31^{* *}$ \\
3. Political trust & 1.47 & .71 & & & $(.72)$ & $.49^{* *}$ \\
4. Satisfaction with public policies & 1.92 & .70 & & & & $.89)$ \\
\hline
\end{tabular}

Note. ${ }^{*} p<.05,{ }^{*} p<.01$. All tests are one-tailed. Values in parentheses are Cronbach's alpha reliability coefficients.

In accordance with $H 1$ and $H 3$, socioeconomic threat was significantly and negatively associated with personal economic satisfaction and political trust. Those who reported higher levels of socioeconomic threat also reported lower levels of personal economic satisfaction $(r(243)=-.14, p<.05)$, and political trust $(r(243)=-.13, p<.05)$.

On the other hand, personal economic satisfaction was significantly and positively correlated with political trust and satisfaction with public policies. Therefore, $H 2$ was also supported. Those who reported higher levels of personal economic satisfaction also reported higher levels of political trust $(r(243)=.41, p<.01)$, and satisfaction with public policies $(r(243)=.31, p<.01)$. Further, satisfaction with public policies, used as a covariate in the model, was significantly and positively associated with political trust. Those who reported higher levels of satisfaction with public policies also reported higher levels of political trust $(r(243)=.49, p<.01)$.

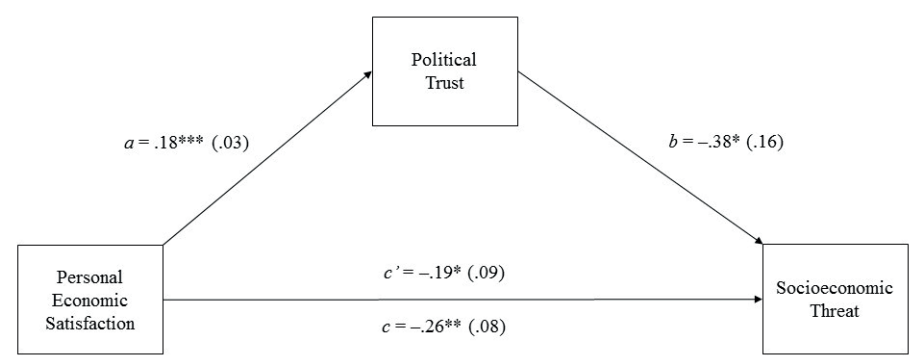

Figure 1. Political trust as mediator of the effect of personal economic satisfaction on socioeconomic threat. Age, city, education, gender, income, and satisfaction with public policies were included in the model as covariates but are not depicted. Path values are unstandardized regression coefficients with standard errors in parentheses $(* p<.05, * * p<.01, * * * p<.001)$. 
As shown in Figure 1 and Table 2, the results indicated that political trust significantly mediated the relation between personal economic satisfaction and socioeconomic threat when controlling for age, city, education, gender, income, and satisfaction with public policies. $H 4$ was thus confirmed.

Table 2. Regression Coefficients, Standard Errors and Model Summary Information

\begin{tabular}{|c|c|c|c|c|c|c|c|c|}
\hline \multirow[b]{3}{*}{ Antecedent } & & \multicolumn{7}{|c|}{ Consequent } \\
\hline & & \multicolumn{3}{|c|}{ Political Trust } & & \multicolumn{3}{|c|}{ Socioeconomic Threat } \\
\hline & & Coeff. & $S E$ & $p$ & & Coeff. & $S E$ & $p$ \\
\hline Personal economic satisfaction & $a$ & .18 & .03 & .00 & $c^{\prime}$ & -.19 & .09 & .02 \\
\hline Political trust & & - & - & - & $B$ & -.38 & .16 & .02 \\
\hline \multirow[t]{2}{*}{ Constant } & $i_{1}$ & -.11 & .26 & .67 & $i_{2}$ & 3.41 & .64 & .00 \\
\hline & & \multicolumn{3}{|c|}{$R^{2}=.67$} & & \multicolumn{2}{|c|}{$R^{2}=.29$} & .01 \\
\hline
\end{tabular}

Considering the total effect model, it was obtained that personal economic satisfaction was a significant predictor of socioeconomic threat $(c=-.26, S E=.08$, $t(225)=-3.22, p<.01)$. Moreover, income $(b=.00, S E=.00, t(225)=2.04, p<.05)$ as a covariate was significantly related to socioeconomic threat perception toward refugees while other control variables including age $(b=.01, S E=.01, t(225)=.72, p=.47)$, city $(b=-.02, S E=.01, t(225)=-1.06, p=.29)$, education $(b=-.04, S E=.10, t(225)=-.44$, $p=.66)$, gender $(b=.00, S E=.16, t(225)=.00, p=1.00)$, and satisfaction with public policies $(b=.19, S E=.12, t(225)=1.53, p=.13)$ were not significantly associated.

For path $a$, personal economic satisfaction significantly predicted political trust ( $a=$ $.18, S E=.03, t(225)=5.35, p<.001)$. Regarding the covariates, gender $(b=.25, S E=$ $.07, t(225)=3.72, p<.001)$, income $(b=.00, S E=.00, t(225)=-2.66, p<.01)$, and satisfaction $(b=.40, S E=.05, t(225)=8.08, p<.001)$ were also significant predictors of political trust in this path, but age $(b=.00, S E=.00, t(225)=.04, p=.97)$, city $(b=$ $.01, S E=.01, t(225)=1.19, p=.23)$, and education $(b=-.01, S E=.04, t(225)=-.13, p$ $=.90)$ were not significant predictors.

Moreover, regarding path $b$, political trust significantly predicted socioeconomic threat $(b=-.38, S E=.16, t(224)=-2.38, p<.05)$. In the indirect effect model, as covariates, satisfaction with public satisfaction $(b=.34, S E=.14, t(224)=2.49, p<.05)$ was significantly related to the perception of refugees as socioeconomic threat whereas age $(b=.01, S E=.01, t(224)=.74, p=.46)$, city $(b=-.01, S E=.01, t(224)=-.88, p=$ 
$.38)$, education $(b=-.05, S E=.10, t(224)=-.46, p=.65)$, gender $(b=.09, S E=.16$, $t(224)=.58, p=.56)$, and income $(b=.00, S E=.01, t(224)=-.88, p=.38)$ were not significantly associated. Finally yet importantly, the regression coefficient for path $c$ ' remained significant, but decreased $\left(c^{\prime}=-.19, S E=.09, t(224)=-2.26, p=.02\right)$, which was indicative of partial mediation (Baron \& Kenny, 1986).

The indirect effect is significant when the CIs do not include zero (Preacher \& Hayes, 2004). The bootstrapped indirect effect of personal economic satisfaction on socioeconomic threat through political trust when controlling for age, city, education, gender, income, and satisfaction with public policies was -.07 and the $95 \%$ confidence interval ranged from -.13 to -.01 . Hence, the indirect effect coefficient was statistically significant. In addition, Sobel's test (1982) was calculated through an interactive calculation tool for mediation tests developed by Preacher and Leonardelli (2001) in order to conduct an inquiry for the possibility of the proposed mediation model. The Sobel's test $(z=-2.21, S E=.03, p<.05)$ also confirmed that the indirect effect was statistically significant.

The findings supported the proposed indirect effect of personal economic satisfaction on socioeconomic threat through political trust, controlling for age, city, education, gender, income, and satisfaction with public services. The indirect effect of -.07 means that participants who differ one unit in their reported personal economic satisfaction levels are estimated to differ by .07 units in a negative direction in their reported perception levels of socioeconomic threat. The indirect effect is due to the tendency for those who are less satisfied with their personal economies to have lower levels of political trust, which in turn translates into higher perception levels of socioeconomic threat.

\section{DISCUSSION}

Previous body of the research (e.g., Blalock, 1967; Riek, Mania, \& Gaertner, 2006; Stephan \& Stephan, 2000) showed that there is a possibility of socioeconomic conflict between host community and refugees, but there has been a lack of studies analyzing its relation to threat perception and political trust. Therefore, the main objective of this study was to explore the socioeconomic conflict between the host community and refugees, and focus on political trust to figure out the underlying mechanisms of this relationship. In particular, the mediating role of political trust on the relationship between personal economic satisfaction and perceived socioeconomic threat toward Syrian refugees in urban Turkey was investigated. 
The research findings showed that personal economic satisfaction predicted the perception of refugees as socioeconomic threat. Refugees were more likely to be perceived as a socioeconomic threat among those who were less satisfied with personal economic conditions. This result can be explained by the Integrated Group Theory (Stephan \& Stephan, 2000), suggesting that rising threat perception to the welfare of a group and its members has considerable effects on creating prejudice and negative attitudes in intergroup relations. For Stephan and Stephan (2000), there is an association between prejudice and perceived threats to ingroup members' economic power. If an ingroup member perceives a disadvantage for personal economy, she or he shows less tolerance to outgroup members (Lawrence, 2011). Regarding the Realistic Group Threat Theory (Blalock, 1967) with a perceived disadvantage for personal economic satisfaction, less tolerance to outgroup members can be explained through competition over scarce sources such as jobs and social benefits (Hochman, 2015) because job opportunities and income levels are two of the most important indicators of satisfaction with personal economic conditions (Filkins et al., 2000). Accordingly, prejudice and competition over scarce sources lead to rising hostility between ingroup and outgroup members (Kamiejski et al., 2012), and end up with socioeconomic threat perceived by the host community toward refugees. Therefore, the Realistic Group Threat Theory (Blalock, 1967) also underlines perceived socioeconomic threat as one of the important factors shaping the relationship between host community and refugees.

The results further indicated that political trust was associated with personal economic satisfaction. Those who were less satisfied with personal economic conditions tended to show less trustworthiness to political institutions. Also, political trust was related to socioeconomic threat perception. Individuals less satisfied with political institutions were more likely to perceive refugees as a socioeconomic threat. More importantly, as hypothesized (H4), it was found that political trust was a significant mediator. In other words, less satisfaction with personal economic conditions caused lower trust in political institutions, which resulted in greater socioeconomic threat perception toward refugees. On the other hand, the findings can also be interpreted as more individuals satisfied with their personal economic conditions had greater trust in political institutions, which led to less perceived socioeconomic threat toward refugees. This finding can be explained through the System Justification Theory (Jost \& Banaji, 1994), which states that those who have an advantage in the society are motivated to see the social structures as fair 
(Harding \& Sibley, 2013). That is to say, personal economic satisfaction enhances system justification and pro-government attitudes. In the case of Turkey, it can be argued that satisfaction with personal economic conditions increases system justification and hence pro-JDP attitudes, which conduces the support of the JDP's pro-refugee policies and consequently lower perception of Syrian refugees as socioeconomic threat. Therefore, system justification might be the underlying mechanism of the relationship between personal economic satisfaction and political trust.

In conclusion, the results of the current study contributed to the Integrated Threat Theory (Stephan \& Stephan, 2000) with an investigation of political trust's mediating role in the relationship between the ingroup's (host community) economic wellbeing and their perception of the outgroup (refugees) as socioeconomic threat. The present research particularly focused on realistic threats. However, exploring the conflicts and relationships between ingroup and outgroup members through political trust with other types of threats as the components of the Integrated Threat Theory such as symbolic threats, intergroup anxiety, and negative stereotypes would be beneficial for future research. Also, Köse et al. (2018) provided evidence that the perception of refugees as socioeconomic threat by host citizens was predicted by social dominance orientation and social egalitarianism in urban Turkey. The current research added to this study as well since political trust was found as another predictor of the perception of refugees as socioeconomic threat in urban Turkey. How social dominance orientation and social egalitarianism moderate and/or mediate the relationship between personal economic satisfaction and socioeconomic threat perception would further be an asset to the literature; to explore the socioeconomic conflict between ingroup and outgroup members from a sociopolitical perspective for future research. Considering the System Justification Theory (Jost \& Banaji, 1994), the potential sequential mediation effects of system justification and political trust on the association between personal economic satisfaction and socioeconomic threat perception toward refugees would also be a future research model in order to identify underlying mechanisms.

There are possible limitations of this study, some of which might be the subject of further studies, contributing to the literature. Since this study employed convenience sampling, and the participants mainly consisted of women, who were middle-aged university graduates and from particular urban cities of Turkey, the conclusions cannot be generalized to an entire population. Therefore, replicating the study in other urban 
cities and groups in Turkey and even other countries hosting Syrian refugees would strengthen the cross-country and cross-culture validity of the proposed model. Particularly testing the model in Lebanon, Jordan, Iraq and Egypt, countries in the Middle East which host refugees from Syria, would be beneficial to have a better understanding of the socioeconomic conflict between host communities and Syrian refugees from a comparative perspective. Furthermore, this study adopted a cross-sectional survey approach. Nonetheless, it is difficult to make causal inferences based on this approach. It should also be noted that the relationship between personal economic satisfaction and socioeconomic threat perception toward refugees cannot be explained through one single mediator. Thus, future research using a longitudinal approach is highly recommended to figure out the directions of the proposed mediation model and also explore other possible mediators. Yet this study focused on the mediating role of political trust on the relationship between personal economic satisfaction and socioeconomic threat perception; political ideology was not regarded, which posed another limitation. For example, the $\mathrm{M}$ generation have an economic wellbeing and is eventually a pro-JDP community (Janmohamed, 2018; Wizsight Research, 2017). However, an opposition person who is satisfied with personal economic conditions may not support the JDP's pro-refugee policies. For this reason, future research may consider political ideology as a moderating variable of the relationship between personal economic satisfaction and political trust. Thus, a moderated mediation model can also be performed in future work.

\footnotetext{
Peer-review: Externally peer-reviewed.

Conflict of Interest: The authors have no conflict of interest to declare.

Grant Support: The authors declared that this study has received no financial support.
}

Hakem Değerlendirmesi: Dış bağımsız.

Çıkar Çatışması: Yazarlar çıkar çatışması bildirmemiştir.

Finansal Destek: Yazarlar bu çalışma için finansal destek almadığını beyan etmiştir.

\section{References/Kaynakça}

Allport, G. (1954). The nature of prejudice. New York: Doubleday.

Ariely, G. (2013). Public administration and citizen satisfaction with democracy: Cross-national evidence. International Review of Administrative Sciences, 79(4), 747-766.

Baron, R. M., \& Kenny, D. A. (1986). The moderator-mediator variable distinction in social psychological research: Conceptual, strategic, and statistical considerations. Journal of Personality and Social Psychology, 51(6), 1173-1182.

Blalock, H. M. (1967). Towards a theory of minority-group relations. New York: Wiley.

Easton, D. (1957). An approach to the analysis of political systems. World Politics, 9(3), 383-400. 
Erçetin, C. (2016). Syrian refugees in tent cities and urban centers in Turkey: Their housing, livelihood, culture, informal economy and social-physical infrastructure. Journal of Current Researches on Social Sciences, 6(1), 155-173.

Erdoğan, M. (2014). Syrians in Turkey: Social acceptance and integration research. Retrieved from https://data2.unhcr.org/en/documents/download/46184

Filkins, R., Allen, J. C., \& Cordes, S. (2000). Predicting community satisfaction among rural residents: An integrative model. Rural Sociology, 65, 72-86.

Fritsche, I., Moya, M., Bukowski, M., Jugert, P., De Lemus, S., Decker, O., Valor-Segura, I., \& NavarroCarrillo, G. (2017). The Great Recession and group-based control: Converting personal helplessness into social class ingroup trust and collective action. Journal of Social Issues, 73(1),117-137.

Girgin, S. Z. S., \& Cebeci, G. T. (2017). The effects of an immigration policy on the economic integration of migrants and on natives' attitudes: The case of Syrian refugees in Turkey. International Journal of Humanities and Social Sciences, 11(4), 1065-1071.

Gorodzeisky, A. (2013). Mechanisms of exclusion: Attitudes toward allocation of social rights to outgroup population. Ethnic and Racial Studies, 36(5), 795-817.

Grönlund, K., \& Setälä, M. (2007). Political trust, satisfaction and voter turnout. Comparative European Politics, 5, 400-422.

Hacaoğlu, S. (2018). A flood of refugees' tests Turkey's tolerance. Retrieved from https://www. bloomberg.com/news/features/2018-12-12/an-endless-flood-of-syrian-refugees-tests-turkey-stolerance

Harding, J. F., \& Sibley, C. G. (2013). The palliative function of system justification: Concurrent benefits versus longer-term costs to wellbeing. Social Indicator Research, 113(1), 410-418.

Hayes, A. F. (2013). Introduction to mediation, moderation, and conditional process analysis: A regression-based approach. New York, NY: The Guilford Press.

Hochman, O. (2015). Infiltrators or asylum seekers? Framing and attitudes toward asylum seekers in Israel. Journal of Immigrant \& Refugee Studies, 13(4), 358-378.

International Crisis Group (2018). Turkey's Syrian refugees: Defusing urban tensions. Retrieved from https://www.crisisgroup.org/europe-central-asia/western-europemediterranean/turkey/248turkeys-syrian-refugees-defusing-urban-tensions

Janmohamed, S. (2018). M nesli yeni müslüman gençlik. Kaknüs Yayınları.

Jeannet, A. M. (2013). Immigration and the erosion of political trust: The moderating role of institutional factors in an enlarged Europe. The Annual Meeting of the Midwestern Political Science Association (MPSA) in Chicago, IL., April 13.

Jost, J. T., \& Banaji, M. R. (1994). The role of stereotyping in system-justification and the production of false consciousness. British Journal of Social Psychology, 33, 1-27.

Kamiejski, R., De Oliveira, P., \& Guimond, S. (2012). Ethnic and religious conflicts in France. In Landis, D. and Albert, R. (Eds.), Handbook of ethnic conflict: International perspectives (pp. 483506). New York, NY, USA: Springer.

Kampen, J. K., Maddens, B., \& Vermunt, J. (2003). Trust and satisfaction: A case-study of the MicroPerformance Theory. In Salminen, A. (Ed.), Governing Networks: EGPA Yearbook (pp. 319-326). Amsterdam: IOS Press.

Kampen, J., Van De Walle, S., \& Bouckaert, G. (2006). Assessing the relation between satisfaction with public service delivery and trust in government: The impact of the predisposition of citizens toward government on evaluations of its performance. Public Performance and Management Review, 29(4), 387-404. 
Köse, A. M., Sunata, U., \& Deniz, E. (2018). Relationships of social dominance orientation and empathy with perception of Syrian refugees as threat: Structural equation modeling with the examples of Çankaya and Altındağ. Sosyal Politika Çalışmaları Dergisi, 40(2), 283-314.

Lawrence, D. F. (2011). Immigration attitudes in Latin America: Culture, economics, and the Catholic Church. The Latin Americanist, 55, 143-170.

LeVine, R. A., \& Campbell, D. T. (1972). Ethnocentrism: Theories of conflict, ethnic attitudes, and group behavior. Oxford, England: John Wiley \& Sons.

Li, L. (2011). The object and substance of trust in central leaders: Preliminary evidence from a pilot survey. The Annual Meeting of the American Political Science Association in Seattle, USA, September 1-4.

Mason, D. S., Kluegel, J. R., \& Khakhulina, L. A. (2000). Marketing democracy: Changing opinion about inequality and politics in East Central Europe. Lanham: Rowman and Littlefield Publishers.

Miller, A. H. (1974). Political issues and trust in government: 1964-1970. The American Political Science Review, 68(3), pp. 951-972.

Muñoz, J., Torcal, M., \& Bonet, E. (2011). Institutional trust and multilevel government in the European Union: Congruence or compensation? European Union Politics, 12(4), 551-574.

Navruz, M., \& Çukurçayır, M. A. (2015). Factors affecting changes in perceptions of Turkish people towards Syrian refugees. International Journal of Social Sciences, 4, 75-84.

Norris, P. (1999). Introduction: The growth of critical citizens? In Norris, P. (Ed.), Critical Citizens (pp. 1-27). Oxford: Oxford University Press.

Nunnally, J. C., \& Bernstein, I. H. (1994. The assessment of reliability. Psychometric Theory, 3, $248-$ 292.

Preacher, K. J., \& Hayes, A. F. (2004). SPSS and SAS procedures for estimating indirect effects in simple mediation models. Behavior Research Methods, Instruments \& Computers, 36(4), 717-731.

Preacher, K. J., \& Leonardelli, G. J. (2001). Calculation for the Sobel test: An interactive calculation tool for mediation tests. Retrieved from http://quantpsy.org/sobel/sobel.htm

Riek, B. M., Mania, E. W., \& Gaertner, S. L. (2006). Intergroup threat and outgroup attitudes: A metaanalytic review. Personality and Social Psychology Review, 10(4), 336-353.

Saad, S., \& Salman, A. (2013). The role of values and political participation. Asian Social Science, 9(8), 9-16.

Schnrider, I. (2016). Can we trust measures of political trust? Assessing measurement equivalence in diverse regime types. Social Indicators Research, 133(3), 963-984.

Schulenberg, S. E., Schnetzer, L. W., \& Buchanan, E. M. (2011). The purpose in life test-short form: Development and psychometric support. Journal of Happiness Studies: An Interdisciplinary Forum on Subjective Well-Being, 12(5), 861-876.

Sobel, M. E. (1982). Asymptotic intervals for indirect effects in structural equations models. Sociological Methodology, 13, 290-312.

Stephan, W., \& Stephan, C. W. (2000). An Integrated Theory of prejudice. In S. Oskamp (Ed.), Reducing prejudice and discrimination (pp. 23-45). New York: Psychology Press.

Tajfel, H. (1981). Human groups and social categories. Cambridge: Cambridge University Press.

Tajfel, H., \& Turner, J. C. (1979). An integrative theory of intergroup conflict. In W. G. Austin \& S. Worchel (Eds.), The social psychology of intergroup relations (pp. 33-48). Monterey, CA: Brooks/Cole.

Topal, M. H., Özer, U., \& Dokuzlu, E. (2017). Public perception of Syrian refugees in Turkey: An empirical explanation using extended Integrative Threat Theory. Problemy Polityki Spolecznej. Studia i Dyskusje, 38(3), 35-58. 
United Nations High Commissioner for Refugees (UNHCR), Government of Turkey (November 27, 2019). Situation Syria regional refugee response. Retrieved from https://data2.unher.org/en/ situations/syria

Van Ryzin, G. G., Muzzio, D., \& Immerwahr, S. (2004). Drivers and consequences of citizen satisfaction: An application of the American Customer Satisfaction Index model to New York City. Public Administration Review, 64(3), 331-341.

Wang, Z. (2005). Before emergence of critical citizens: Economic development and political trust in China. International Review of Sociology, 15(1), 155-71.

Wizsight Research (2017). A guide to understand A+ conservatives. Marketing Türkiye, 334, 70-74.

Wong, T. K., Wan, P., \& Michael Hsiao, H. H. (2011). The bases of political trust in six Asian societies: Institutional and cultural explanations compared. International Political Science Review, 32(3), 263-281.

Yitmen, Ş., \& Verkuyten, M. (2018). Positive and negative behavioural intentions towards refugees in Turkey: The roles of national identification, threat, and humanitarian concern. Journal of Community \& Applied Social Psychology, 28(4), 230-243.

Zhong, Y. (2014). Do Chinese people trust their local government, and why? Problems of PostCommunism, 61(3), 31-44. 
